\title{
Infection and Colonization of Rice Seedlings by the Plant Growth-Promoting Bacterium Herbaspirillum seropedicae Z67
}

\author{
Euan K. James, ${ }^{1}$ Prasad Gyaneshwar, ${ }^{1}$ Natarajan Mathan, ${ }^{1}$ Wilfredo L. Barraquio, ${ }^{2}$ \\ Pallavolu M. Reddy, ${ }^{1}$ Pietro P.M. Iannetta, ${ }^{3}$ Fabio L. Olivares, ${ }^{4}$ and Jagdish K. Ladha ${ }^{1}$ \\ ${ }^{1}$ International Rice Research Institute, DAPO Box 7777, Metro Manila, Philippines; ${ }^{2}$ Institute of Biology, University of the \\ Philippines, Diliman, Quezon City 1101, Philippines; ${ }^{3}$ Genes to Products, Quality, Health and Nutrition, Scottish Crops \\ Research Institute, Invergowrie, Dundee DD2 5DA, U.K.; ${ }^{4}$ Setor de Citologia Vegetal, Lab. Biologia Celular e Tecidual, \\ Centro de Biociências e Biotecnologia, Universidade Estadual do Norte Fluminense, Campos dos Goytacazes, \\ RJ 28015-620, Brazil
}

Submitted 28 December 2001. Accepted 27 April 2002.

\begin{abstract}
A $\beta$-glucoronidase (GUS)-marked strain of Herbaspirillum seropedicae $\mathrm{Z67}$ was inoculated onto rice seedling cvs. IR42 and IR72. Internal populations peaked at over $10^{6} \log$ CFU per gram of fresh weight by 5 to 7 days after inoculation (DAI) but declined to $10^{3}$ to $10^{4} \log$ CFU per gram of fresh weight by 28 DAI. GUS staining was most intense on coleoptiles, lateral roots, and at the junctions of some of the main and lateral roots. Bacteria entered the roots via cracks at the points of lateral root emergence, with cv. IR72 appearing to be more aggressively infected than cv. IR42. $H$. seropedicae subsequently colonized the root intercellular spaces, aerenchyma, and cortical cells, with a few penetrating the stele to enter the vascular tissue. Xylem vessels in leaves and stems were extensively colonized at 2 DAI but, in later harvests ( 7 and 13 DAI), a host defense reaction was often observed. Dense colonies of $\boldsymbol{H}$. seropedicae with some bacteria expressing nitrogenase $\mathrm{Fe}$-protein were seen within leaf and stem epidermal cells, intercellular spaces, and substomatal cavities up until 28 DAI. Epiphytic bacteria were also seen. Both varieties showed nitrogenase activity but only with added $C$, and the dry weights of the inoculated plants were significantly increased. Only cv. IR42 showed a significant (approximately 30\%) increase in $N$ content above that of the uninoculated controls, and it also incorporated a significant amount of ${ }^{15} \mathbf{N}_{2}$.
\end{abstract}

Additional keywords: nitrogen fixation, immunogold labeling, electron microscopy, endophytic diazotrophs.

Wetland rice (Oryza sativa L.) is one of the most important cereals in the world, with low-input (particularly of $\mathrm{N}$ ) agriculture contributing over $86 \%$ of the total crop. However, rice yields in these low-input systems are generally low (typically only 1 to 3.5

Corresponding author: E. K. James; Telephone +44 1382 344741; Fax: +44 1382 345893; E-mail: e.k.james@dundee.ac.uk.

Current address of E. K. James: Centre for High Resolution Imaging and Processing, MSI/WTB Complex, School of Life Sciences, University of Dundee, Dundee DD1 5EH, U.K.

Current address of P. M. Reddy: CIFN-UNAM, Cuernavaca, Mexico.

Current address of P. Gyaneshwar: Department of Plant and Microbial Biology, University of California, Berkeley, 94720-3102, U.S.A. $\mathrm{t} \mathrm{ha}^{-1}$ ) and must be increased by at least $50 \%$ in order to meet the demands of the projected rise in world population by the year 2025 (James et al. 2000; Ladha and Reddy 1995; Ladha et al. 1997). This will require double the amount of nitrogen that is currently applied to the crop as fertilizer, which is neither economically nor environmentally desirable. Therefore, an alternative approach is to increase the contribution to rice agriculture made by biological nitrogen fixation (BNF), utilizing the natural associations between members of the Gramineae and associative diazotrophic bacteria (Ladha et al. 1997).

A number of recent studies in the Philippines (Malarvizhi and Ladha 1999; Shrestha and Ladha 1996; Wu et al. 1995), Pakistan (Malik et al. 1997; Mirza et al. 2000), and Brazil (Boddey et al. 1995) have shown that some wetland varieties (most notably and consistently, IR42), can fix up to $30 \%$ of their $\mathrm{N}$ needs in the absence of any contributions from phototrophic bacteria. In addition, a large and diverse range of $\mathrm{N}_{2^{-}}$ fixing heterotrophic bacteria have been isolated from surfacesterilized rice plants (Barraquio et al. 1997; Ebeltagy et al. 2001; Engelhard et al. 2000; Gyaneshwar et al. 2001; Stoltzfus and de Bruijn 2000; Verma et al. 2001; Yanni et al. 1997). Some of these bacteria, most notably Alcaligenes faecalis A15 (now renamed Pseudomonas stutzeri A15; Vermeiren et al. 1999), Azoarcus spp., Herbaspirillum spp., Rhizobium spp., and Serratia marcescens IRBG500 have been confirmed by microscopy to be genuine endophytes of rice (Reinhold-Hurek and Hurek, 1998a, 1998b; James et al. 2000). Of these endophytic diazotrophs, one of the most promising in terms of rice BNF is $H$. seropedicae. This was first evidenced by the work of Boddey and associates (1995), showing that fluctuations in acetylene reduction activity (ARA) of cv. IR42 under field conditions could be correlated with fluctuations in the $H$. seropedicae population. More recently, ${ }^{15} \mathrm{~N}$ isotope dilution data from Baldani and associates (2000) has shown that the two H. seropedicae strains Z67 and Z94, isolated from rice in Brazil (Baldani et al. 1986, 1996), could contribute as much as 54 and $31 \% \mathrm{~N}$, respectively, to rice seedlings in laboratory experiments and less (approximately 18\%) in subsequent greenhouse experiments. Similar data (i.e., 39\% nitrogen derived from air [Ndfa]) have also been obtained by Mirza and associates (2000) with rice inoculated with Herbaspirillum sp. strain RR8. Therefore, in consideration of the potential importance of $H$. seropedicae to BNF in wetland rice, in the present study, we examined the infection and colonization of two rice varieties 

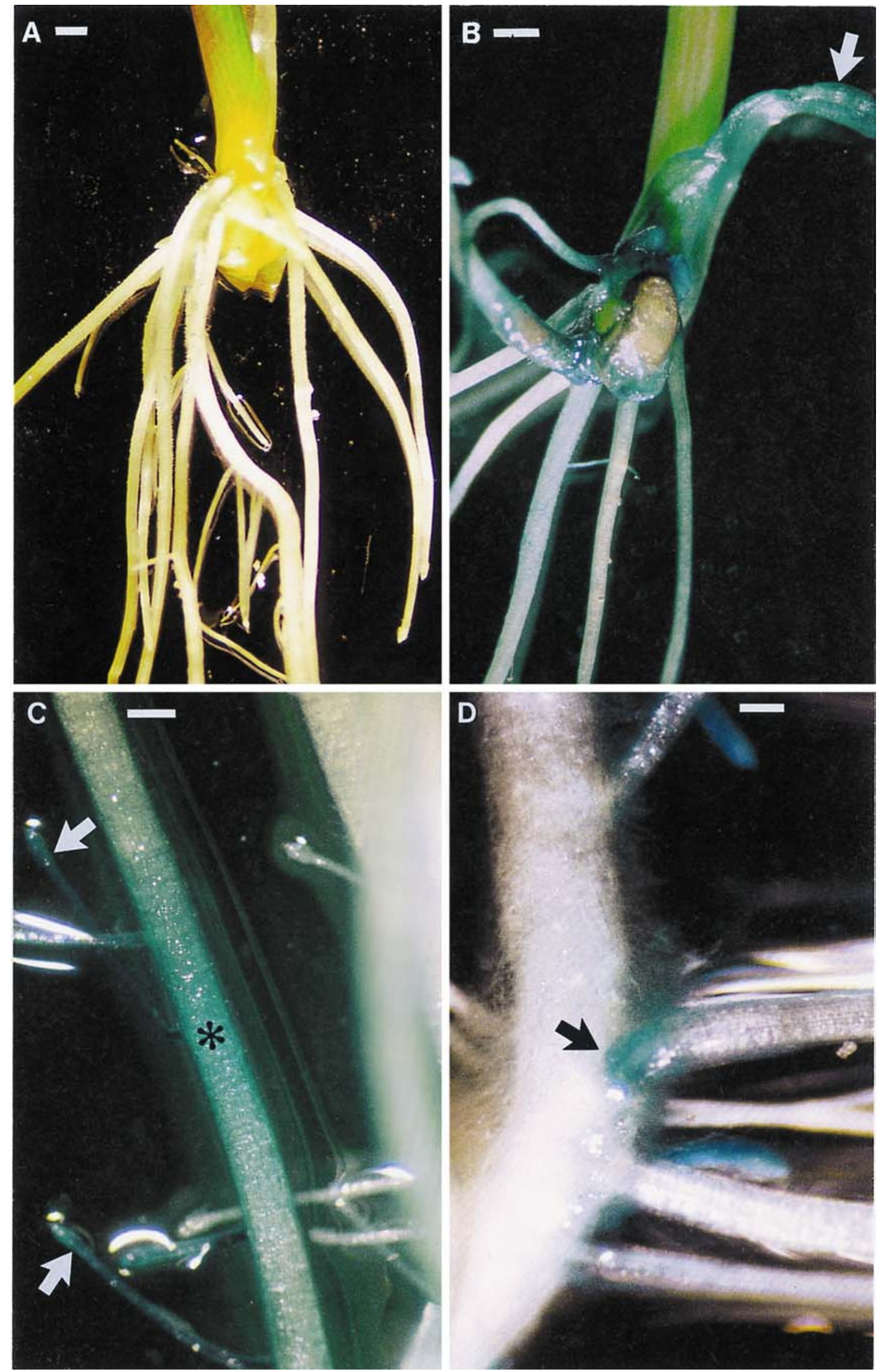

Fig. 1. $\beta$-Glucuronidase (GUS) staining of rice seedlings (cv. IR72) at 2 days after inoculation by $H$. seropedicae Z67-gusA. A, Upper root system and lower stem of an uninoculated control plant after incubation in X-Gluc for 4 to $6 \mathrm{~h}$. There is no visible blue coloration. Bar $=1 \mathrm{~mm}, \mathbf{B}, \mathrm{Upper}$ root system and lower stem showing blue coloration, indicating the presence of gus-labeled bacteria on the surface. Note that the coleoptile is particularly strongly stained (arrow). Bar $=1 \mathrm{~mm}$. C, Detail of the upper part of a main root showing blue staining on the surface due to GUS activity $(*)$. The lateral roots are particularly strongly stained (arrows). Bar $=500 \mu \mathrm{m}$. D, Detail of a lateral root junction showing strong GUS staining (arrow). Bar $=200 \mu \mathrm{m}$. 
by the type strain Z67 marked with gusA (Barraquio et al. 1997) and assessed its potential as a diazotrophic plant growthpromoting rhizobacterium under laboratory conditions.

\section{RESULTS}

\section{Population dynamics of $H$. seropedicae Z67-GUS on and within rice seedlings.}

The overall pattern of bacterial population growth was similar for both rice varieties (data not shown). The surface populations of the roots were always slightly higher than those of the aerial parts (stems plus leaves) and peaked at $\log 6$ to $8 \mathrm{CFU}$ per gram of fresh weight between 2 and 7 DAI, declining to approximately $\log 4 \mathrm{CFU}$ per gram of fresh weight by the end of the experiment at 28 DAI. The "internal" bacterial populations (i.e., those obtained from surface-sterilized plants) followed a very similar pattern to the surface populations, with those in the roots being slightly higher than in the aerial parts. However, there were some varietal differences, e.g., the internal populations in $\mathrm{cv}$. IR72 peaked at 5 to $7 \mathrm{DAI}$, whereas those of cv. IR42 peaked at 7 to 10 DAI. These differences between varieties in the internal populations of their aerial parts had disappeared by $13 \mathrm{DAI}$, and the bacterial populations in both varieties had declined to $\log 3$ to $4 \mathrm{CFU}$ per gram of fresh weight by 28 DAI. No $H$. seropedicae could be isolated from the uninoculated control plants throughout the experiments.

\section{Localization of $H$. seropedicae Z67-GUS on and within rice seedlings.}

None of the uninoculated control plants showed any blue coloration with 5-bromo-4-chloro-3-indoxyl-beta-D-glucuronate (X-Gluc) throughout the experiment (Fig 1A). However, with the inoculated plants, parts of the roots and the basal parts of the stems of both varieties stained blue when examined for GUS activity at 2 DAI (cv. IR72, Fig. 1B, C, and D), and this activity was observed on the roots, stems, and leaves at all harvests up to 28 DAI (not shown). Close examination of the inoculated roots at 2 DAI revealed that the GUS activity was mainly associated with the coleoptiles (Fig. 1B) and the surfaces of some of the main roots (Fig. 1B and C). The lateral roots (Fig. 1C) and some of the junctions of the lateral and main roots were particularly densely stained (Fig. 1D).

Further analysis of GUS-stained material using light and transmission electron microscopy (TEM) showed that H. seropedicae Z67 aggressively entered the primary roots by 2 DAI, although the two varieties differed in the degree of aggression by which the herbaspirilla invaded and colonized them (Figs. 2 and 3). With cv. IR72, the invasion process involved large numbers of the bacteria colonizing cracks at lateral root junctions (Fig. 2A and B) and then entering them "en masse" (Fig. 2C and D). The bacteria multiplied within the cracks and moved more deeply into the primary roots via intercellular spaces (Fig. 2C and D). Occasionally, and close to the points of infection, bacteria were observed within minor xylem vessels of both primary and lateral roots (Fig. 2E and F) although, in general, the bacteria rarely penetrated the stele, being localized primarily within the cortical intercellular spaces and in the aerenchyma (Figs. $2 \mathrm{C}$ to $\mathrm{E}$ and $3 \mathrm{C}$ ). In the case of cv. IR42, the invasion process followed a similar pattern to cv. IR72 but appeared to be less aggressive, as fewer bacteria were observed entering the roots (Fig. 3A and B). As with roots of cv. IR72, the herbaspirilla were principally localized within aerenchyma and intercellular spaces (Fig. 3A and B), but unlike in cv. IR72, they were never observed within the stele or vascular system (not shown). The bacteria in both varieties were identified by immunogold labeling with a $H$. seropedicae-specific antibody (Fig. 2F and data not shown).
In the roots of cv. IR72, within which bacteria had established in very high numbers by 2 DAI, a dark-staining, electron-dense material filled some of the cortical intercellular spaces (Fig. 3C and D). This material was similar to that observed surrounding some of the bacteria during the "crack" entry process (Fig. 2D). In most roots, however, there was no obvious host response to their presence at this early stage. In both varieties, herbaspirilla were commonly observed within the large cells that were destined to die and become the lysigenous aerenchyma typical of wetland rice (Justin and Armstrong 1987; Kawai et al. 1998) (Figs. 2E and 3B to D). In cv. IR72, some bacteria were immunogold labeled using an antibody raised against nitrogenase component II (Fig. 3E), although most were not. Control serial sections for immunogold labeling did not show significant gold labeling (Fig. 3F).

By 2 DAI, the aerial parts were also heavily infected by $H$. seropedicae, and as with the roots, there were some differences in the degree to which the two varieties were infected. In leaves of cV. IR72, the herbaspirilla had formed numerous dense intercellular colonies (Fig. 4A and B). The bacteria within these colonies had expanded the spaces far beyond their normal volume (Fig. 4A and B), and the cell walls bounding the bacteria were greatly thickened (Fig. 4C). Intercellular herbaspirilla were also commonly seen within leaves of cv. IR42 (Fig. 4D), but unlike in cv. IR72 (Fig. 4A to C), they had not multiplied to such an extent that the spaces had become greatly swollen. Interestingly, epiphytic bacteria could be seen on the leaves of both varieties (Fig. 4A and D), and in cv. IR42, some of these herbaspirilla appeared to actually enter (or exit) the leaves via cracks in the epidermis (Fig. 4D). At 2 DAI in both varieties, bacteria were frequently observed within stem aerenchyma (Fig. 4E) and in vascular tissue (Fig. 4E and F). There was no obvious defense response from the host in either of these locations, except for the production of a sparse fibrillar material within infected xylem parenchyma cells of cv. IR72 (Fig. 4F). As with those colonizing the roots, the identity of the bacteria in the leaves was confirmed by immunogold labeling to be $H$. seropedicae (Fig. 4B, C, and F). The gold-labeling was also present on material that appeared to have been released from the surfaces of either the bacteria, the fibrillar material, or both mentioned previously (Fig. 4F).

Bacteria were not so readily localized within roots in later harvests, and the crack entry processes observed at 2 DAI were rarely seen. However, herbaspirilla could still be found in sections of stems and leaves, particularly in cv. IR72, within which there were macroscopically visible lesions that were stained blue with X-gluc (data not shown). At these points, there was evidence of massive intercellular and vascular invasion (Fig. 5A), as well as clear signs that bacteria had probably entered or exited by stomata, subsequently forming large colonies in substomatal cavities (Fig. 5A and B). In other leaves at 7 DAI, herbaspirilla were localized more discretely within epidermal and parenchyma cells (Fig. 5C and D); occasionally, intercellular bacteria were observed attempting to enter these via damaged cell walls (Fig. 5E). None of the infected host cells appeared to have intact cytoplasm, and all the cells were most probably dead, either prior to or as a result of the bacterial invasion (Fig. 5C to E). Also at $7 \mathrm{DAI}$, the bacterial infection of cv. IR72 appeared to have provoked the occlusion of some of the stem xylem vessels by material that stained pink-purple (data not shown) with toluidine blue (Fig. 5F). No bacteria were visible within these when they were examined under the TEM, although intercellular bacteria were close by (data not shown). By 13 DAI, the aerial parts of cv. IR72 were still showing signs of pathogenicity, such as yellowing of the leaves (data not shown). The stems of these plants were highly infected by herbaspirilla, with the bacteria being localized 
throughout the central tissue, mainly within intercellular spaces and aerenchyma (Fig. 6A) and also xylem vessels (data not shown). By the final harvest (28 DAI), there was little sign of extensive infection in cv. IR72, but herbaspirilla could still be observed on roots of cv. IR42 (data not shown) and also within leaves of this variety (Fig. 6B to F). For example, in necrotic leaf tips showing high GUS activity, the central parts were degraded, and the resulting cavities as well as adjacent damaged

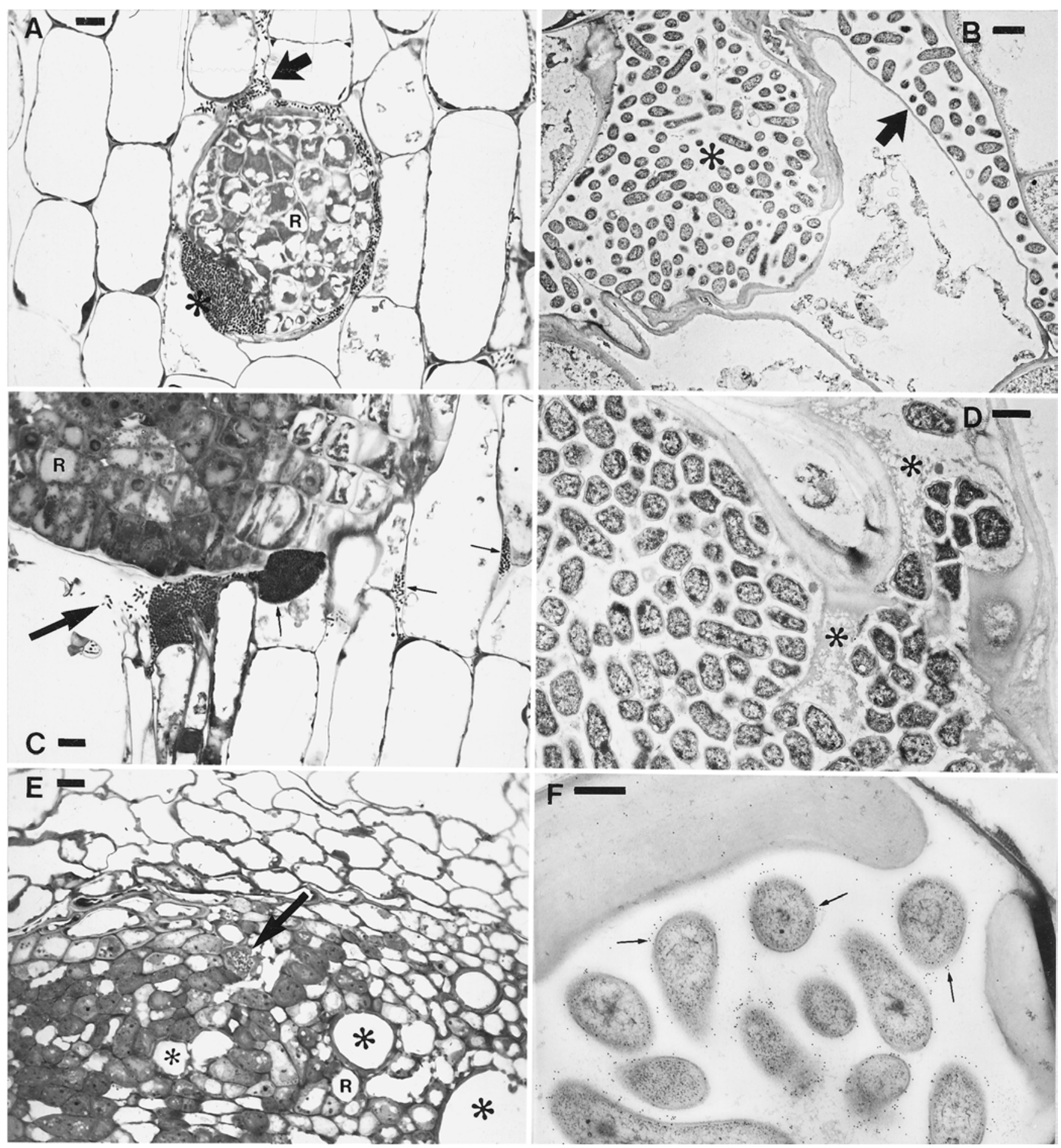

Fig. 2. Light microscopy (A, C, and $\mathbf{E})$ and transmission electron microscopy $(\mathbf{B}, \mathbf{D}$, and $\mathbf{F})$ of sections through junctions of main and lateral roots (R) of rice seedlings (cv. IR72) at 2 days after inoculation by H. seropedicae Z67-gusA. A and $\mathbf{B}$, Transverse sections through the base of a lateral root at a point just below the surface of the main root that it subtends. Cavities surrounding the emerging lateral root are filled with bacteria (*), and the intercellular spaces that connect with these also contain bacteria (arrows). $\mathbf{C}$ and $\mathbf{D}$, Longitudinal sections through the base of a lateral root at a point just below the surface of the main root that it subtends. In C, a large colony of bacteria has entered the main root via a "crack" (large arrow) at the junction of the lateral, and the bacteria have penetrated deeply into the cortex of the main root through the network of intercellular spaces (small arrows), while $\mathbf{D}$, shows detail of bacteria within the "crack" as well as a fibrillar material that surrounds the bacteria, particularly at the "leading edge" of the colony (*). E, Transverse section through a main root, showing a longitudinal section of the vascular system of a lateral root as it emerges from the main root. Most of the xylem vessels (*) do not contain bacteria, but one of the minor vessels in the emerging lateral is full of bacteria (large arrow), and in $\mathbf{F}$, the bacteria within the vessel are shown to be immunogold labeled with an antibody raised against $H$. seropedicae Z67 (arrows). Bar $=10 \mu \mathrm{m}$ in $\mathbf{A}, \mathbf{C}$, and $\mathbf{E}, 2 \mu \mathrm{m}$ in $\mathbf{B}, 1 \mu \mathrm{m}$ in $\mathbf{D}$, and $500 \mathrm{~nm}$ in $\mathbf{F}$. 
cells contained numerous bacteria (Fig. 6B), many of which were degraded or senescent in appearance (Fig. 6C). These bacteria, as well as material released from them, were immunogold labeled with the anti-H. seropedicae antibody (Fig. 6C). In other leaves, herbaspirilla were mainly present within small intercellular spaces (Fig. 6D and E), and some of these bacteria expressed the Fe-protein of nitrogenase (Fig. 6F).

No bacteria were seen in control plants at any stage in any experiment (data not shown).

\section{Effect of $H$. seropedicae $\mathrm{Z67}-G U S$ on nitrogenase activity and plant growth.}

No ARA could be detected with either variety at any harvest, even at 10 DAI when populations of bacteria (internal plus external) were generally at their highest. Nitrogenase (acetylene reduction) activity was, however, observed when the rooting medium of the plants was supplemented with an additional carbon source (5 $\mathrm{mM}$ sodium malate), and cv. IR42 showed greater activity than cv. IR72 (Table 1).

At the end of the experiment (28 DAI), inoculated plants showed a significant increase in dry weight compared to the controls and, in the case of cv. IR42, a significant increase in total $\mathrm{N}$ content of over $30 \%$ (Table 2). In a separate but identical experiment, in which inoculated and uninoculated plants of cv. IR42 were exposed to an atmosphere enriched in ${ }^{15} \mathrm{~N}_{2}$ for 3 days, the inoculated plants had incorporated significantly more ${ }^{15} \mathrm{~N}$ than the control plants when harvested at 10 DAI (Table 3).

\section{Cellulase and pectinase activity.}

Qualitative plate assays showed that both $H$. seropedicae Z67 and H. rubrisubalbicans M4 could digest pectin and cellulose, with the latter strain giving a slightly stronger reaction with both assays (data not shown).

\section{DISCUSSION}

\section{Infection and colonization.}

This study has shown that $H$. seropedicae Z67 can enter the roots of two rice varieties via cracks at lateral root junctions and rapidly colonize the intercellular spaces, aerenchyma, and xylem of the roots and aerial parts. Although there have been some preliminary reports of the "crack entry" process occurring when rice is infected with rhizobia (Chantreuil et al. 2000; Gopalaswamy et al. 2000), this is the first study to show it in any detail with an endophytic diazotroph such as $H$. seropedicae. Indeed, the present study of rice, together with that of Gough and associates (1997) with Arabidopsis and those of James and Olivares (1998) and Olivares and James (2000) with sugar cane, have shown that $H$. seropedicae has a preference for infecting plants via such an aggressive means of entry. However, and in contrast to Arabidopsis (Gough et al. 1997), $H$. seropedicae can also multiply within rice and, subsequently, massively colonize the intercellular spaces and aerenchyma, even entering some of the cortical cells. This aggressive infection and colonization occurs surprisingly quickly, i.e., within two days of inoculation. James and Olivares (1998) and Olivares and James (2000) have reported similar findings with sugar cane roots inoculated with either $H$. seropedicae or its phytopathogenic relative, $H$. rubrisubalbicans, and it may be of significance that both rice and sugar cane are natural hosts of Herbaspirillum spp., whereas dicots such as Arabidopsis are not (Olivares et al. 1996). Interestingly, contrasting results to our study have recently been obtained with an endophytic Herbaspirillum sp. (strain B501) isolated from wild rice. This bacterium was shown to readily colonize the aerial parts but not the roots when inoculated on to its host, Oryza officinalis
(Ebeltagy et al. 2001), and therefore the ability to enter roots may not be a universal feature of all Herbaspirillum spp. strains.

To be able to infect roots so readily, H. seropedicae Z67 must possess cell wall-degrading enzymes, such as cellulase or pectinase, or both (Ebeltagy et al. 2001; Hallmann et al. 1997; Kovtunovych et al. 1999; Reinhold-Hurek and Hurek 1998a, 1998b; Verma et al. 2001), and qualitative plate assays have shown that these are released in low quantities by both $H$. seropedicae Z67 and its close relative, H. rubrisubalbicans M4 (this study). The present study also showed that the aggressive infection by $H$. seropedicae Z67 occasionally elicited a localized host defense response (especially in cv. IR72) in the form of a fibrillar material surrounding intercellular bacteria or occluding xylem vessels, or both. The production of cell wall-degrading enzymes by phytopathogenic bacteria is usually linked with this type of response by the plant (Hallmann et al. 1997). However, in common with other (nonpathogenic) plant-associated diazotrophs, such as Azoarcus, Azospirillum, and Klebsiella spp. (Patriquin et al. 1983; Reinhold-Hurek et al. 1993; Kovtunovych et al. 1999), the amount of these enzymes produced by $H$. seropedicae is relatively small compared to pathogens and may be completely suppressed once the bacteria are established within the plant. This may explain the relatively minor and localized nature of the host response, particularly in the later harvests. The gradual decline (or dilution) in bacterial population within surface-sterilized roots and aerial parts shown by all three varieties after 10 DAI is similar to that observed with a number of other studies with endophytic bacteria (Hallmann et al. 1997). This decline probably reflects the nonpathogenic nature of most bacterial endophytes (discussed above), including the initially aggressive $H$. seropedicae as, unlike true pathogens, they lack an ability to overcome the plant's defenses and the spatial limitations that the latter impose upon them, particularly as the plants grow in size and vigor beyond the seedling stage (Hallmann et al. 1997). Nevertheless, despite the reduction in their numbers to only $\log 3$ to $4 \mathrm{CFU}$ per gram of fresh weight, by $28 \mathrm{DAI}$ the Herbaspirillum spp. populations in surface-sterilized plants of all three varieties had stabilized. Moreover, it was still possible to localize the bacteria within the aerial parts of plants (especially cv. IR42) up until this final harvest (Fig. 6B to F), thus showing that $H$. seropedicae can persist within rice far beyond the early stages of infection.

One of the principal locations of $H$. seropedicae Z67 was the aerenchyma in both roots and aerial parts. These large cells are present in many species of flooding-tolerant grasses and they are preprogrammed to die and produce gas spaces ("lysigenous" aerenchyma) to assist in aeration of flooded organs, especially the roots (Justin and Armstrong 1987; Kawai et al. 1998). A number of previous studies have shown bacteria living within aerenchyma of members of the subtribe Gramineae, such as unidentified bacteria in $\mathrm{N}_{2}$-fixing roots of Spartina alterniflora (McClung et al. 1983; Patriquin et al. 1983), Azoarcus spp. in kallar grass roots (Hurek et al. 1994; ReinholdHurek and Hurek 1998a, 1998b) and Azoarcus and Serratia spp. in roots and stems of rice (Egener et al. 1999; Gyaneshwar et al. 2001; James et al. 2000). As these cells are already dead or dying, this presumably assists in their colonization by bacteria without provoking more than a localized defense response. Indeed, it has even been suggested that most cells external to the endodermis of mature wetland rice roots are actually dead or dying (Hurek et al. 1994), and hence it may be that this region can be considered as simply an extension of the rhizosphere. Certainly, it is unlikely that intact cells of rice or other members of the subtribe Gramineae are ever colonized by endophytic bacteria without subsequently causing either the 


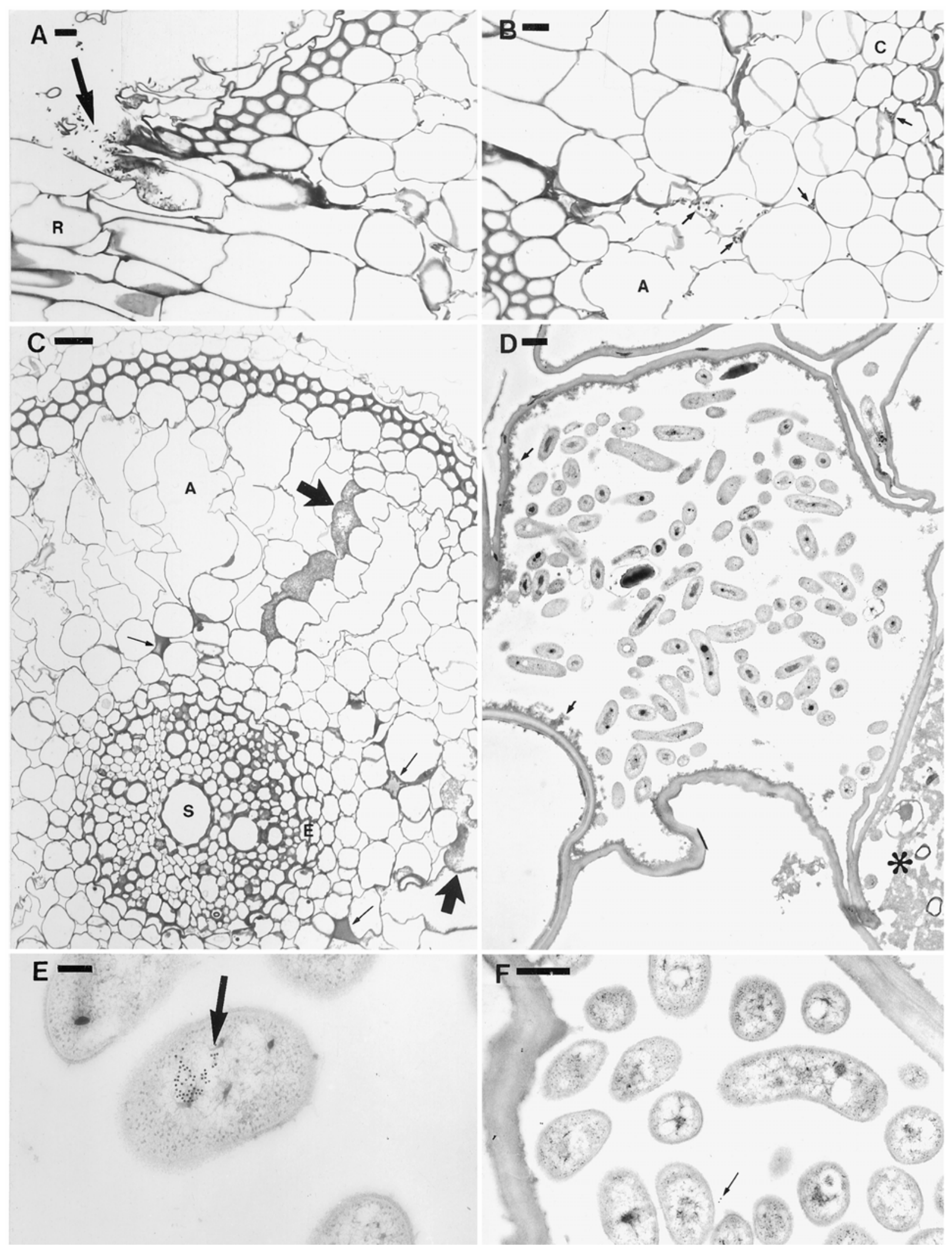

Fig. 3. Light microscopy (A and B) of transverse sections through junctions of main and lateral roots (R) of rice seedlings (cv. IR42) at 2 days after inoculation by $H$. seropedicae Z67-gusA. A, Bacteria accumulating in a cavity (arrow) at the base of an emerging lateral root. Bar $=10 \mu \mathrm{m}$. B, Intercellular bacteria (small arrows) moving deeper into the aerenchyma (A) and cortex $(\mathbf{C})$ of the main root. Bar $=10 \mu \mathrm{m}$. $\mathbf{C}$, Light microscopy and $\mathbf{D}, \mathbf{E}$, and F, transmission electron microscopy of sections through main roots of rice seedlings (cv. IR72) at 2 days after inoculation by H. seropedicae Z67gusA. C, Transverse section through a main root, close to a lateral root junction. The root is heavily infected with bacteria (large arrows), which are mainly located within the aerenchyma (A). A dark-staining material (small arrows) has accumulated in some of the cortical intercellular spaces close to the endodermis (E). The stele (S) appears to be uninfected. Bar $=20 \mu \mathrm{m}$. D, Bacteria within an enlarged cortical cell that is destined to contribute to the lysigenous root aerenchyma. Remnants of the cytoplasm can be seen at the edges of the cell (small arrows). Note that the adjacent cell, or intercellular space, contains electron dense material $(*)$. Bar $=1 \mu \mathrm{m}$. One of the intracellular bacteria in $\mathbf{E}$ is immunogold labeled with antibodies raised against the Fe ( $\mathrm{NifH}$ ) protein of nitrogenase (arrow), while those in $\mathbf{F}$ were "labeled" with nonimmune serum (arrow). Bar $=500 \mathrm{~nm}$ in $\mathbf{E}$ and $200 \mathrm{~nm}$ in $\mathbf{F}$. 
lysis of the bacteria, the degradation of the host cell cytoplasm, or both (Hallmann et al. 1997; James 2000; James and Olivares 1998; Olivares et al. 1997; Reinhold-Hurek and Hurek 1998a, 1998b; this study).
Although herbaspirilla were observed within the stems and leaves throughout the experiment, there were no obvious and direct links between them and the bacteria within the roots. Nevertheless, a number of connecting routes can be envisaged.
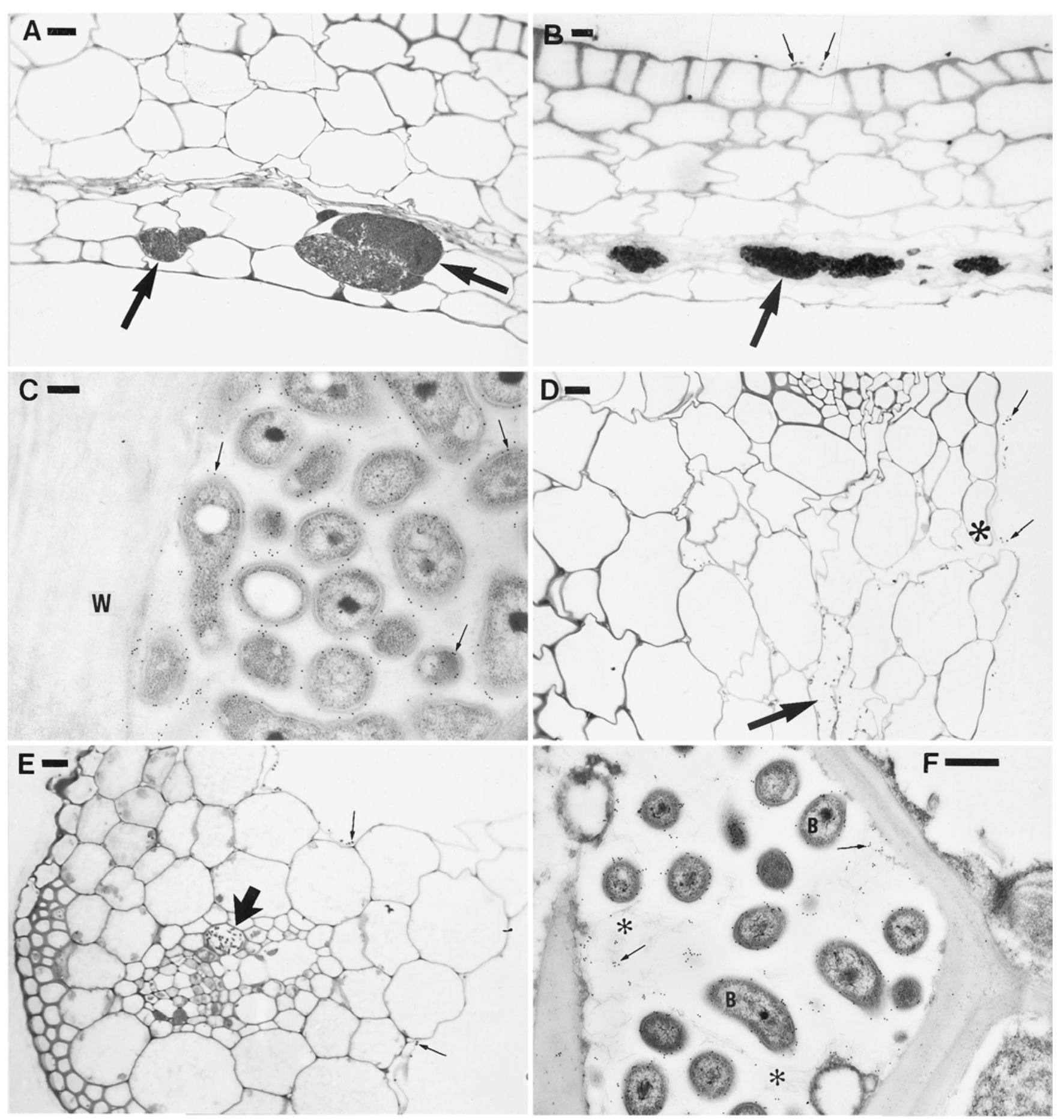

Fig. 4. Light microscopy (A, B, D, and $\mathbf{E})$ and transmission electron microscopy (B and $\mathbf{F})$ of transverse sections through the aerial parts of rice seedlings of cvs. IR72 (A, B, C, and F) and IR42 (D and $\mathbf{E})$ at 2 days after inoculation by H. seropedicae Z67-gusA. A, B, and C, Leaves of cv. IR72 with very dense intercellular colonization by bacteria, particularly on the lower side of the leaf where the bacteria have greatly expanded the volume of the spaces that contain them (large arrows in $\mathbf{A}$ and $\mathbf{B}$ ). The sections in $\mathbf{B}$ and $\mathbf{C}$ were immunogold labeled with an antibody raised against $H$. seropedicae Z67 (followed by silver-enhancement in B), and the labeled bacteria can be seen either as black regions (arrow in B) or as individual bacteria with gold particles being localized mainly on their surfaces (arrows in C). Note that the cell wall (W) adjacent to the bacteria in $\mathbf{C}$ is greatly thickened. D, A leaf of cv. IR42 showing less dense colonization of intercellular spaces (large arrow) by bacteria that may have entered via a break in the epidermis $(*)$. Epiphytic bacteria are present on both varieties (small arrows in $\mathbf{B}$ and $\mathbf{D}$ ). $\mathbf{E}$ and F, Stems of cvs. IR42 and IR72, respectively. In E, bacteria can be seen in a metaxylem vessel as well as in nearby aerenchyma (small arrows), whereas in F, the immunogold-labeled bacteria (B) are within a lignified xylem parenchyma cell. Note that the bacteria in $\mathbf{F}$ are associated with a fibrillar material (*), and some of this is also immunogold labeled (arrows). In A, B, D, and $\mathbf{E}$, Bars $=10 \mu \mathrm{m}$; in $\mathbf{C}, 200 \mathrm{~nm}$; and in $\mathbf{F}, 500 \mathrm{~nm}$. 
First, it is possible that some of the bacteria within the root xylem vessels were transported to the aerial parts in the transpiration stream, as has been suggested previously for other endophytic diazotrophs in grasses (Hurek et al. 1994; James and Olivares 1998; James et al. 1994). Against this, however, the herbaspirilla were rarely seen within root xylem vessels, and then only in cv. IR72. Second, intercellular spaces and particularly the large cavities formed by the aerenchyma may have provided a conduit for the bacteria to spread within the plants. This has recently been partly demonstrated by the studies of Prayitno and associates (1999) and Ebeltagy and associates (2001), which showed, respectively, that R4, a $R$. leguminosarum bv. trifolii strain originally isolated from rice by Yanni and associates (1997), and $H$. seropedicae sp. B501gfp formed long lines of intercellular bacteria down the lateral roots or aerial parts of inoculated plants. A third possibility is direct infection of the aerial parts by epiphytic herbaspirilla. The presence of herbaspirilla on leaf surfaces is shown clearly in Figures 4A, B, and D and 5A and B. Furthermore, some bacteria were even observed apparently entering a wound in the epidermis of a leaf of cv. IR42 at 2 DAI (Fig. 4D), whereas in cv. IR72, the herbaspirilla were shown at 7 DAI to be densely colonizing stomatal cavities (Fig. 5A and B) in a manner very redolent of $H$. rubrisubalbicans in mottled stripe disease-susceptible sugar cane leaves (Olivares et al. 1997; James and Olivares 1998; Olivares and James 2000). The fourth possibility is that bacteria within the semisolid rooting medium entered the emerging coleoptile in the early stages of plant growth and then migrated to the other aerial parts. This is suggested by the strong GUS staining of the coleoptiles at 2 DAI (Fig. 1B).

Irrespective of the mode of entry of herbaspirilla in stems and leaves, they were mainly localized within intercellular spaces, dead cells, and xylem vessels. These locations are similar to those observed in aerial parts of other members of the subtribe Gramineae infected by Herbaspirillum spp., such as sorghum and sugar cane infected by either $H$. seropedicae or H. rubrisubalbicans (James and Olivares 1998; James et al. 1997; Olivares et al. 1997). Consistent with its apparently "nonpathogenic" nature on other Gramineae spp. (James et al. 1997; Olivares et al. 1997; Pimentel et al. 1991), no macroscopically visible disease symptoms were observed on rice leaves infected with $H$. seropedicae, except for some slight yellowing of leaves of cv. IR72 at 13 DAI and of cv. IR42 at 28 DAI. Moreover, far from being detrimental to the plants, there was clear evidence of growth promotion caused by the presence of the bacteria in both varieties, including IR72 (Table 2). On the other hand, the pattern (although not the severity) of the rice leaf and stem colonization with its dense colonies of intercellular, substomatal, and xylem bacteria (e.g., with cv. IR72 at 7 and 13 DAI [Figs. 5A and B and 6A] and with cv. IR42 at 28 DAI [Fig. 6B and C]) had many similarities to that shown by $H$. rubrisubalbicans in disease-susceptible varieties of sugar cane (Olivares et al. 1997) and sorghum (James et al. 1997). Therefore, the present study of rice illustrates well the apparently paradoxical nature of $H$. seropedicae, in that it can extensively colonize tissues of Gramineae spp. in an almost pathogenic manner, but at the same time, it has the potential to promote the growth of the infected plants.

\section{Nitrogenase activity and growth promotion.}

With both varieties, inoculation with $H$. seropedicae Z67 resulted in significant nitrogenase (acetylene reduction) activity at the time of peak bacterial populations (10 DAI). Additionally, and as with Azoarcus spp. colonizing the interior of rice and kallar grass (Egener et al. 1999; Hurek et al. 1994; Reinhold-Hurek and Hurek 1998a, 1998b), nifH protein could also be localized in a limited number of the herbaspirilla within the roots and aerial parts, until the end of the experiments (28 DAI). On the other hand, ARA was only obtained when a C source (sodium malate) was added, thus indicating that $\mathrm{N}_{2}$ fixation by the cells, both on and within the plants, was C-limited. Similarly, in a recent study of rice seedlings inoculated with an $\mathrm{N}_{2}$-fixing strain of Serratia marcescens, Gyaneshwar and associates (2001) only observed nitrogenase activity (ARA) after C was added. This is also often the case with other Gramineae spp., e.g., ARA and nifH expression of Azospirillum brasilense on wheat (Triticum aestivum) roots was dependent on added $\mathrm{C}$ (Christiansen-Weniger et al. 1992; Vande Broek et al. 1993), and Chelius and Triplett (2000) recently showed that endophytic strains of Klebsiella pneumoniae could express dinitrogenase reductase in roots and stems of maize (Zea mays) but only after sucrose was added to the rooting medium.

The ${ }^{15} \mathrm{~N}_{2}$ experiment in the present study confirmed the very low (albeit significant) $\mathrm{N}_{2}$ fixation in the interaction between one of the varieties (IR42) and H. seropedicae Z67. Similarly, Ebeltagy and associates (2001) also obtained low values when they tested the $\mathrm{N}_{2}$-fixing ability of Herbaspirillum sp. strain $\mathrm{B} 501$ in association with wild rice. The low $\mathrm{N}_{2}$ fixation in the present study and in that of Ebeltagy and associates (2001) contrasts with a recent study performed by Gyaneshwar and associates (2002), in which a rice variety tolerant to aluminum (Moroberekan) was inoculated with $H$. seropedicae Z67 and compared with an Al-intolerant variety, IR45. Only cv. Moroberekan gave significant levels of ARA without any added $\mathrm{C}$, and ${ }^{15} \mathrm{~N}_{2}$ experiments showed that cv. Moroberekan in combination with $H$. seropedicae Z67 could actually derive over $4 \%$ of it's $\mathrm{N}$ content (Ndfa) from $\mathrm{N}_{2}$ fixation over a 3-day period, which was nearly 10 times greater than that shown by cv. IR45 $(0.42 \% \mathrm{Ndfa})$ or that by cv. IR42 in the present study ( $0.45 \%$ Ndfa; Table 3$)$. The ability of cv. Moroberekan to fix significant quantities of $\mathrm{N}$ independently of added $\mathrm{C}$ was attributed to a relatively large amount of $\mathrm{C}$ in its root exudates, which were twice that of cv. IR45 (Gyaneshwar et al. 2002). Similarly, Baldani and associates (2000) used ${ }^{15} \mathrm{~N}$ isotope dilution with axenically-grown plants to show that an upland variety of rice, "Guarani", when inoculated with $H$. seropedicae Z94 could obtain more than $50 \%$ of its $\mathrm{N}$ requirements from $\mathrm{N}_{2}$ fixation. Taken together, these studies suggest that the ability of rice to support or benefit, or both, from $\mathrm{N}_{2}$ fixation by $H$. seropedicae is possible but is also both highly variable and very much dependent on plant genotype.

\section{MATERIALS AND METHODS}

\section{Plant growth conditions and inoculation.}

Dehulled seeds of the wetland rice cvs. IR72 and IR42 were surface sterilized for $5 \mathrm{~min}$ with $70 \%$ ethanol followed by $0.2 \%$ mercuric chloride for $30 \mathrm{~s}$ and were washed three times with sterile water. The seeds were germinated on $0.1 \%$ tryptic soya agar plates, and seedlings free of visual bacterial and fungal contamination were transferred to $80 \mathrm{ml}$ glass tubes $(20 \mathrm{~cm}$ in height) with $20 \mathrm{ml}$ Fahraeus medium without nitrogen (Fahraeus 1957) for 3 days. H. seropedicae Z67 marked with gusA (Barraquio et al. 1997) was then used for inoculation. The bacteria were grown in Luria broth supplemented with spectinomycin $(100 \mu \mathrm{g}$ per $\mathrm{ml})$ until they reached an optical density of 0.6 . The cells were then harvested by centrifugation, washed twice with normal saline, and re-suspended in phosphate-buffered saline before being used for inoculation. Half of the seedlings were inoculated with $1 \mathrm{ml}$ of the suspension containing approximately $10^{7}$ herbaspirilla, and the other half were left as uninoculated controls. At the start of the experiment, the tubes were plugged with a plastic top, but at $7 \mathrm{DAI}$, the plastic top 
was removed from the tubes and replaced with a strip of laboratory film with a small hole pierced in it to allow the shoot to emerge. The seedlings were grown for a total of 28 days in a growth chamber with a $14 \mathrm{~h}$ light and $10 \mathrm{~h}$ dark cycle under an irradiance level of $50 \mu \mathrm{mol} \mathrm{m} \mathrm{m}^{-2} \mathrm{~s}^{-1}$ and with day and night temperatures of 27 and $25^{\circ} \mathrm{C}$, respectively.

\section{Enumeration of bacteria.}

Replicate ( 3 to 4 ) inoculated and control plants were sampled at various times throughout the experiments, from 1 to 28 DAI. In each case, loosely attached bacteria were first removed by washing the roots and aerial parts (stem plus leaves) in sterile water, followed by immersion in fresh sterile water and by
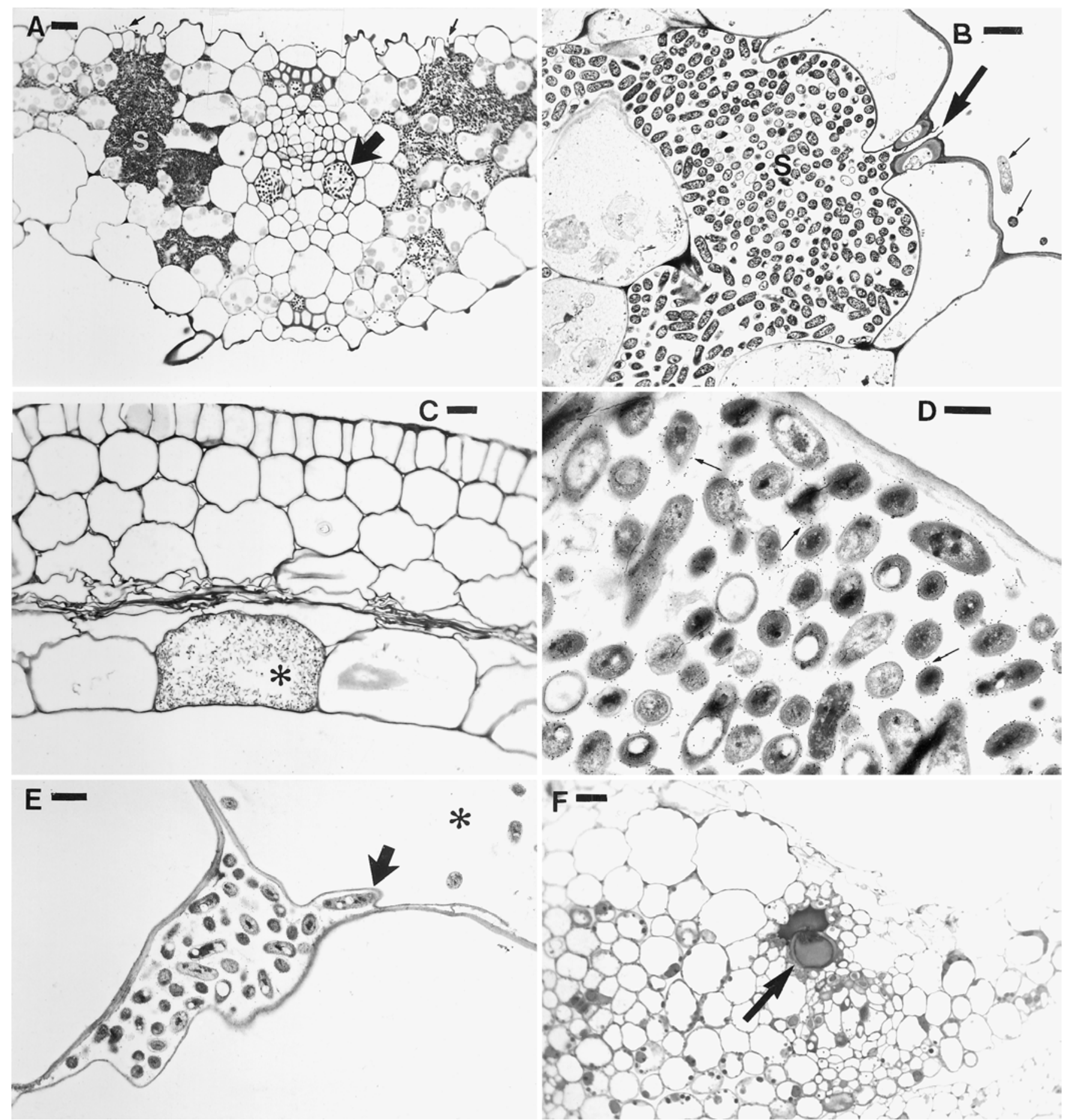

Fig. 5. Light microscopy (A, C, and $\mathbf{F}$ ) and transmission electron microscopy $(\mathbf{B}, \mathbf{D}$, and $\mathbf{E}$ ) of transverse sections through the aerial parts of rice seedlings, cv. IR72, at 7 days after inoculation by H. seropedicae Z67-gusA. A, Very dense colonization of metaxylem in a major vein (large arrow) as well as in the intercellular spaces and substomatal cavities (S) on either side of it. Note that there are epiphytic bacteria close to some of the stomata (small arrows), and these may have entered or exited via the stomatal apertures (large arrow in $\mathbf{B}$ ). $\mathbf{C}, \mathbf{D}$, and $\mathbf{E}$, Leaf epidermal cells colonized by bacteria (*). The bacteria in $\mathbf{D}$ and $\mathbf{E}$ were immunogold labeled with an antibody raised against $H$. seropedicae Z67 (arrows in $\mathbf{D}$ ). The cell in $\mathbf{E}$ is in the process of being invaded by intercellular bacteria (arrow). Note the absence of cytoplasm in the bacterial-colonized cells in $\mathbf{D}$ and $\mathbf{E}$. F, Tranvserse section of the central part of the stem showing a xylem vessel and associated lacuna filled with material that stains intensely with toluidine blue (arrow). In $\mathbf{A}, \mathbf{C}$, and $\mathbf{F}$, Bars $=10 \mu \mathrm{m}$; in $\mathbf{B}, 2 \mu ; \mathbf{D}, 500 \mathrm{~nm}$; and $\mathbf{E}, 1 \mu \mathrm{m}$. 
vortexing for $30 \mathrm{~s}$. The resulting solutions were serially diluted and placed on Luria broth agar plates containing $100 \mu \mathrm{g}$ of spectinomycin per $\mathrm{ml}$ and $40 \mu \mathrm{g}$ of X-Gluc per ml. Bacterial colonies showing blue coloration were then counted and were assumed to be those bacteria that were closely associated with the plant surface. In another set, the roots and aerial parts were surface sterilized by immersion in $95 \%$ ethanol for 5 min followed by treatment with $3 \%$ calcium hypochlorite containing $0.1 \%$ sodium dodecyl sulfate for $1 \mathrm{~min}$. After three washes with sterile distilled water followed by maceration in saline, the homogenate was serially diluted and plated on Luria agar as described above. The saline solution before maceration was


Fig. 6. Light microscopy (A, B, and $\mathbf{D})$ and transmission electron microscopy $(\mathbf{C}, \mathbf{E}$, and $\mathbf{F})$ of transverse sections through the aerial parts of rice seedlings of A, cv. IR72 at 13 days after inoculation (DAI) or B, C, D, E, and F, cv. IR42 at 28 DAI by H. seropedicae Z67-gusA. A, Transverse section through the upper stem with bacteria colonizing intercellular spaces (arrows) and aerenchyma (A) throughout the developing leaf. B and C, Sections through a leaf tip with a degraded central part that has collapsed to form a lumen $\left.*^{*}\right)$ containing numerous bacteria that are immunogold labeled with an antibody raised against $H$. seropedicae Z67. Some of the bacteria in $\mathbf{C}$, are senescent in appearance $(*)$. Note that the immunogold labeling is also present on debris (arrows) as well as on intact bacteria (B). D, Transverse section through a leaf with numerous small colonies of intercellular bacteria (large arrows) that are labeled with antibodies raised against $\mathbf{E}$, H. seropedicae $\mathrm{Z67}$ or against $\mathbf{F}$, the $\mathrm{Fe}(\mathrm{NifH})$ protein of nitrogenase. Some bacteria can also be seen on the leaf surface (small arrows). Note that there is a break (*) in the lower side of the leaf in $\mathbf{D}$, possibly allowing access to the aerenchyma (A). In $\mathbf{A}$, Bars $=20$ $\mu \mathrm{m}$; in $\mathbf{B}$ and $\mathbf{D}, 10 \mu \mathrm{m} ; \mathbf{C}, 500 \mathrm{~nm} ; \mathbf{E}, 200 \mathrm{~nm}$; and $\mathbf{F}, 100 \mathrm{~nm}$. 
seedlings served as controls. The total amount of $\mathrm{N}$ fixed was calculated according to Nayak and associates (1986) as (atom $\%{ }^{15} \mathrm{~N}$ excess of sample/atom $\%{ }^{15} \mathrm{~N}$ excess of gas) $\times$ total $\mathrm{N}$. $\mathrm{Ndfa}$ was calculated as $\% \mathrm{Ndfa}=\left\{\right.$ [atom $\%{ }^{15} \mathrm{~N}$ excess (tissue) - atom $\%{ }^{15} \mathrm{~N}$ excess (background) $] /\left[\right.$ atom $\%{ }^{15} \mathrm{~N}$ excess (atmosphere) - atom $\%{ }^{15} \mathrm{~N}$ excess (background) $\left.]\right\} \times 100$ where atom $\%{ }^{15} \mathrm{~N}$ (background $)=0.010 \pm 0.006$ and atom $\%{ }^{15} \mathrm{~N}$ excess of atmosphere $=4.9$.

\section{Analysis of cellulose- and pectin-degrading activity.}

This was performed according to Mateos and associates (1992) with some modifications. NFb agar (without malate but with $0.2 \%$ tryptone) containing either $0.1 \%$ carboxymethyl cellulose (CMC), $0.5 \%$ sodium polypectate, or $0.5 \%$ pectin was spot-inoculated with liquid cultures (grown in $\mathrm{NFb}$ without agar) of $H$. seropedicae $\mathrm{Z} 67$ and $H$. rubrisubalbicans M4. The plates were incubated at $37^{\circ} \mathrm{C}$ for 3 days. After incubation, the bacterial cells were removed, and the $\mathrm{CMC}$-containing plates were stained with Congo red (1 mg per $\mathrm{ml}$ ) for $30 \mathrm{~min}$, followed by several washes with $1 \mathrm{M} \mathrm{NaCl}$. Similarly, after removal of the cells, the pectin-containing plates were stained with $2 \%$ hexadecyl trimethyl ammonium bromide for $30 \mathrm{~min}$, followed by washing with $1 \mathrm{M} \mathrm{NaCl}$. Cellulose- and pectin-degrading activity was determined visually by the appearance of a halo around the points where the bacteria were inoculated.

\section{ACKNOWLEDGMENTS}

We thank J. I. Sprent for helpful discussions. A. R. Prescott is thanked for the use of electron microscope facilities at the University of Dundee We are grateful to M. Alumaga, G. Baeta da Cruz, M. Gruber, M. Kierans, R. Hernandez-Oane, and R. So for technical assistance. The financial assistance for this work was partly provided by grants from Gesellschaft fur Technishe Zusammenarbeit (GTZ) and the Carnegie Trust and partly by the Department of Biological Sciences, University of Dundee.

\section{LITERATURE CITED}

Baldani, J. I., Baldani, V. L. D., Seldin, L., and Döbereiner, J. 1986. Characterization of Herbaspirillum seropedicae gen. nov., sp. nov., a root associated nitrogen fixing bacterium. Int. J. Syst. Bacteriol. 36:86-93.

Baldani, J. I., Pot, B., Kirchhof, G., Falsen, E., Baldani, V. L. D. Olivares, F. L., Hoste, B., Kersters, K., Hartmann, A., Gillis, M., and Döbereiner, J. 1996. Emended description of Herbaspirillum; inclusion of [Pseudomonas] rubrisubalbicans, a mild plant pathogen, as Herbaspirillum rubrisubalbicans comb. nov.; and classification of a group of clinical isolates (EF group 1) as Herbaspirillum species 3. Int. J. Syst. Bacteriol. 46:802-810.

Baldani, V. L. D., Baldani, J. I., and Döbereiner J. 2000. Inoculation of rice plants with the endophytic diazotrophs Herbaspirillum seropedicae and Burkholderia spp. Biol. Fertil. Soils 30:485-489.

Barraquio W. L., Revilla, L., and Ladha, J. K. 1997. Isolation of endophytic diazotrophic bacteria from wetland rice. Plant Soil 194:15-24.

Boddey, R. M., de Oliveira, O. C., Urquiaga, S., Reis, V. M., Olivares, F. L., Baldani, V. L. D., and Döbereiner, J. 1995. Biological nitrogen fixation associated with sugar cane and rice: Contributions and prospects for improvement. Plant Soil 174:195-209.

Chantreuil C., Giraud, E., Prin, Y., Lorquin, J., Ba, A., Gillis, M., de Lajudie, P., and Dreyfus, B. 2000. Photosynthetic Bradyrhizobia are natural endophytes of the African wild rice Oryza breviligulata. Appl. Environ. Microbiol. 66:5437-5447.

Chelius, M. K., and Triplett, E. W. 2000. Immunolocalization of dinitrogenase reductase produced by Klebsiella pneumoniae in association with Zea mays. Appl. Environ. Microbiol. 66:783-787.

Christiansen-Weniger, C., Groneman, A. F., and van Veen, J. A. 1992. Associative $\mathrm{N}_{2}$ fixation and root exudation of organic acids from wheat cultivars of different aluminum tolerance. Plant Soil 139:167-174.

Ebeltagy, A., Nishioka, K., Sato, T., Suzuki, H., Ye, B., Hamada, T., Isawa, T., Mitsui, H., and Minamisawa, K. 2001. Endophytic colonization and in planta nitrogen fixation by a Herbaspirillum sp. isolated from wild rice. Appl. Environ. Microbiol. 67:5285-5293.

Egener, T., Hurek, T., and Reinhold-Hurek, B. 1999. Endophytic expression of nif genes of Azoarcus sp. strain BH72 in rice roots. Mol. PlantMicrobe Interact. 12:813-819.
Engelhard, M., Hurek, T., and Reinhold-Hurek, B. 2000. Preferential occurrence of diazotrophic endophyte, Azoarcus sp. in wild rice species and land races of Oryza sativa in comparison with modern races. Environ. Microbiol. 2:131-141.

Fahraeus, A. 1957. The infection of clover root hairs by nodule bacteria studied by a simple glass slide technique. J. Gen. Microbiol. 16:374381.

Gopalaswamy, G., Kannaiyan, S., O'Callaghan, K. J., Davey, M. R., and Cocking, E. C. 2000. The xylem of rice (Oryza sativa) is colonized by Azorhizobium caulinodans. Proc. Roy. Soc. Lond. B. 267:103-107.

Gough, C., Galera, C., Vasse, J., Webster, G., Cocking, E. C., and Dénarié, J. 1997. Specific flavonoids promote intercellular root colonization of Arabidopsis thaliana by Azorhizobium caulinodans ORS571. Mol. Plant-Microbe Interact. 10:560-570.

Gyaneshwar, P., James, E. K., Mathan, N., Reddy, P.M., Reinhold-Hurek, B., and Ladha, J. K. 2001. Endophytic colonization of rice by a diazotrophic strain of Serratia marcescens. J. Bacteriol. 183:2634-2645.

Gyaneshwar, P., James, E. K., Reddy, P. M., and Ladha, J. K. 2002. Herbaspirillum colonization increases growth and nitrogen accumulation in aluminium tolerant rice varieties. New Phytol. 154:131-146.

Hallmann, J., Quadt-Hallmann, A., Mahaffee, W. F., Kloepper, J. W. 1997. Bacterial endophytes in agricultural crops. Can. J. Microbiol 43:895-914.

Hurek, T., Reinhold-Hurek, B., Van Montagu, M., and Kellenberger, E. 1994. Root colonization and systemic spreading of Azoarcus sp. strain BH72 in grasses. J. Bacteriol. 176:1913-1923.

James, E. K. 2000. Nitrogen fixation in endophytic and associative symbiosis. Field Crops Res. 65:197-209.

James, E. K., and Olivares, F. L. 1998. Infection and colonization of sugarcane and other graminaceous plants by endophytic diazotrophs. Crit. Rev. Plant Sci. 17:77-119.

James, E. K., Reis, V. M., Olivares, F. L., Baldani, J. I., and Dobereiner, J. 1994. Infection of sugar cane by the nitrogen-fixing bacterium Acetobacter diazotrophicus. J. Exp. Bot. 275:757-766.

James, E. K., Olivares, F. L., Baldani, J. I., and Dobereiner, J. 1997. Herbaspirillum, an endophytic diazotroph colonizing vascular tissue in the leaves of Sorghum bicolor L. Moench. J. Exp. Bot. 48:785-797.

James, E. K., Gyaneshwar, P., Mathan, N., Barraquio, W. L., and Ladha, J. K. 2000. Endophytic diazotrophs associated with rice. Pages 119140 in: The Quest for Nitrogen Fixation in Rice. J. K. Ladha and P. M. Reddy, eds. International Rice Research Institute, Makati City, Philippines.

Jefferson, R. A., Kavanagh, T. A., and Bevan, M. W. 1987. GUS fusions: $\beta$-glucoronidase as a sensitive and versatile gene fusion marker in higher plants. EMBO (Eur. Mol. Biol. Organ.) J. 6:3901-3907.

Justin, S. H. F. W., and Armstrong, W. A. 1987. The anatomical characterization of roots and plant response to soil flooding. New Phytol. 106:465-495

Kawai, M., Samarajeewa, P. K., Barrero, R. A., Nishiguchi, M., and Uchimiya, H. 1998. Cellular dissection of the degradation pattern of cortical cell death during aerenchyma formation of rice roots. Planta 204:277-287.

Kovtunovych, G., Lar, O., Kamalova, S., Kordyum, V., Kleiner, D., and Kozyrovska, N. 1999. Correlation between pectate lyase activity and ability of diazotrophic Klebsiella oxytoca VN13 to penetrate into plant tissues. Plant Soil 215:1-6.

Ladha, J. K., and Reddy, P. M. 1995. Extension of nitrogen fixation to rice - necessity and possibilities. Geojournal 35:363-372.

Ladha, J. K., de Bruijn, F. J., and Malik, K. A. 1997. Assessing opportunities for nitrogen fixation in rice: A frontier project. Plant Soil 194:110.

Malarvizhi, P., and Ladha, J. K. 1999. Influence of available N and rice genotype on associative nitrogen fixation. Soil Sci. Soc. Am. J. 63:93-99.

Malik, K. A., Rakhshanda, B., Mehnaz, S., Rasul, G., Mirza, M. S., and Ali, S. 1997. Association of nitrogen-fixing, plant growth promoting rhizobacteria (PGPR) with Kallar grass and rice. Plant Soil 194:37-44.

Mateos, P. F., Jimenez-Zurdo, J. I., Chen, J., Squartini, A. S., Haack, S. K., Martinez-Molina, E., Hubbell, D. H., and Dazzo, F. B. 1992. Cellassociated pectinolytic activity and cellulolytic enzymes in Rhizobium leguminosarum biovar trifolii. App. Environ. Microbiol. 58:18161822.

McClung, C. R., van Berkum, P., Davis, R. E., and Sloger, S. 1983. Enumeration and localization of $\mathrm{N}_{2}$-fixing bacteria associated with roots of Spartina alterniflora Loisel. Appl. Environ. Microbiol. 45:1914-1920.

Mirza, M. S., Rasul, G., Mehnaz, S., Ladha, J. K., So, R. B., Ali, S., and Malik, K. A. 2000. Beneficial effects of inoculated nitrogen-fixing bacteria on rice. Pages 191-204 in: The Quest for Nitrogen Fixation in Rice. J. K. Ladha and P. M. Reddy, eds. International Rice Research Institute, Makati City, Philippines.

Nayak D. N., Ladha J. K., and Watanabe I. 1986. The fate of marker 
Azospirillum lipoferum inoculated into rice and it's effect on growth yield and $\mathrm{N}_{2}$-fixation of plants studied by acetylene reduction, ${ }^{15} \mathrm{~N}_{2}$ feeding and ${ }^{15} \mathrm{~N}$ dilution techniques. Biol. Fert. Soils 2:7-14.

Olivares, F. L., and James, E. K. 2000. Endophytic establishment of diazotrophic bacteria in sugar cane plants. Pages 413-414 in: Nitrogen Fixation: From Molecules to Crop Productivity. F. O. Pedrosa, M. Hungria, M. G. Yates, and W. E. Newton, eds. Kluwer, Dordrecht, The Netherlands.

Olivares, F. L., Baldani, V. L. D., Reis, V. M., Baldani, J. I., Döbereiner, J. 1996. Occurrence of the endophytic diazotrophs Herbaspirillum spp. in roots, stems and leaves predominantly of Gramineae. Biol. Fertil. Soils 21:197-200.

Olivares, F. L., James, E. K., Baldani, J. I., and Dobereiner, J. 1997. Infection of mottled stripe disease susceptible and resistant varieties of sugarcane by the endophytic diazotroph Herbaspirillum. New Phytol. 35:723-737.

Patriquin, D. G., Döbereiner, J., and Jain, D. K. 1983. Sites and processes of association between diazotrophs and grasses. Can. J. Microbiol. 29:900-915

Pimentel, J. P., Olivares, F. L., Pitard, R. M., Urquiaga, S., Akiba, F., and Döbereiner, J. 1991. Dinitrogen fixation and infection of grass leaves by Pseudomonas rubrisubalbicans and Herbaspirillum seropedicae. Plant Soil 137:61-65.

Prayitno, J., Stefaniak, J., McIver, J., Weinman, J. J., Dazzo, F. B., Ladha, J. K., Barraquio, W., Yanni, Y. G., and Rolfe, B. G. 1999. Interactions of rice seedlings with bacteria isolated from rice roots. Aust. J. Plant Physiol. 26:521-535.

Reinhold-Hurek, B., and Hurek, T. 1998a. Interactions of gramineous plants with Azoarcus spp. and other diazotrophs: Identification, localization and perspectives to study their function. Crit. Rev. Plant Sci. 17:29-54.

Reinhold-Hurek, B., and Hurek, T. 1998b. Life in grasses: Diazotrophic endophytes. Trends Microbiol. 6:139-144.
Reinhold-Hurek, B., Hurek, T., Claeyssens, M., and van Montagu, M. 1993. Cloning, expression in Escherichia coli, and characterization of cellulytic enzymes of Azoarcus sp., a root-invading diazotroph. J. Bacteriol. 175:7056-7065.

Shrestha, R. K., and Ladha, J. K. 1996. Genotypic variation in promotion of rice nitrogen fixation as determined by ${ }^{15} \mathrm{~N}$ dilution. Soil Sci. Soc. Am. J. 60:1815-1821.

Stoltzfus, J. R., and de Bruijn, F. J. 2000. Evaluating diazotrophy, diversity and endophytic colonization ability of bacteria isolated from surface-sterilized rice. Pages 63-92 in: The Quest for Nitrogen Fixation in Rice. J. K. Ladha and P. M. Reddy, eds. International Rice Research Institute, Makati City, Philippines.

Vande Broek, A., Michiels, J., Van Gool, A., and Vanderleyden, J. 1993. Spatial-temporal colonization patterns of Azospirillum brasilense on the wheat root surface and expression of the bacterial nifH gene during association. Mol. Plant-Microbe Interact. 6:592-600.

Verma, S. C., Ladha, J. K., and Tripathi, A. K. 2001. Evaluation of plant growth promoting and colonization ability of endophytic diazotrophs from deep water rice. J. Biotechnol. 91:127-141.

Vermeiren, H., Willems, A., Schoofs, G., de Mot, R., Keijers, V., Hai, W., and Vanderleyden, J. 1999. The rice inoculant strain Alcaligenes faecalis A15 is a nitrogen-fixing Pseudomonas stutzeri. Syst. Appl. Microbiol. 22:215-224.

Wu, P., Zhang, G., Ladha, J. K., McCouch, S. R., and Huang, N. 1995. Molecular-marker-facilitated investigation on the ability to stimulate $\mathrm{N}_{2}$ fixation in the rhizosphere by irrigated rice plants. Theor. Appl. Genet. 91:1171-1183.

Yanni, Y. G., Rizk, R. Y., Corich, V., Squartini, A., Ninke, K., PhilipHollingsworth, S., Orgambide, G., de Bruijn, F. D., Stoltzfus, J., Buckley, D., Schmidt, T. M., Mateos, P. F., Ladha, J. K., Dazzo, F. B. 1997. Natural endophytic associations between Rhizobium leguminosarum bv. trifolii and rice roots and assessment of its potential to promote rice growth Plant Soil 194:99-114. 